\title{
Teachers' Attitude Towards Inclusive Education in Nepal
}

\author{
Puspa Sharma \\ Ministry of Federal Affairs and General Administration \\ xrmapuspa337@gmail.com
}

\begin{abstract}
This article assesses attitude of teachers towards inclusive education by their age, gender, qualifications, training, disability and teaching experience. Under the quantitative survey design, 63 teachers from four schools participated in the study, who responded to a Likert questionnaire measuring attitude towards inclusive education. Teachers are found generally positive towards inclusive education. In a Likert scale ranging from 1 to 5(highly positive), the overall attitude of teachers is 3.32.Looking attitude by gender, male teachers are found slightly positive towards inclusive education than female ones. Similarly, younger teachers are found positive than older teachers. Trained and experienced teachers are also found positive than untrained and inexperienced ones. In addition, teachers with some disability are found to have more positive attitude than other group of teachers.
\end{abstract}

Keywords : Inclusive education, integrated schools, special schools, attitude, Likert Scale

\section{Introduction}

Education is considered as a fundamental right of every human being. The Article 26 of United Nations' Universal Declaration of Human Rights states that 'everyone has a right to education' and education is free at least up to the primary and basic level (United Nations, 1948). The Education for All (2000 - 2015) and Millennium Development Goals underscores equally the right to education for all children. Accordingly, Nepal has incorporated right to education as a fundamental right of all citizens in the country. The Article 31 of its Constitution 2072 B.S has ensured this right to all children, making a legal provision that "every citizen shall have the right to get compulsory and free education up to the basic level and free education up to the secondary level from the State" (Government of Nepal, 2072 B.S.). Therefore, it is the responsibility of the state to ensure quality education to all children regardless of their ethnicity, language, and economic status, gender, disability status.

Nepal is a multicultural and multi-ethnic country. The National Population Census of 2011 has recorded 125 caste/ethnic groups in Nepal. In addition, there are 123 different languages spoken as mother tongue. Similarly, there are different ten religion categories are reported in the National Census of 2011 (Central Bureau of Statistics, 2014). According to the National 
Census 2011, there are 23.15million people in Nepal, and among them 79.89 million are in the central Region. It is estimated that approximately 11 out of every 100 in Nepal are suffering from one form of disability or another. This means nearly 1.94 percent of the total population has some sort of disability. Among this physical disability constitute 36.3 percent of the population with disability followed by blindness/low vision (18.5\%) Deaf/hard of hearing (15.4\%) Speech problem (11.5\%) Multiple disability (7.5\%) Mental disability (6.1) Intellectual disability (2.9) Autism (3\%), and Deaf-blind (1.8). Almost all of them are living below poverty line.

Teachers are key agents for delivering/imparting knowledge to the students. They are the key persons in realizing the goals of inclusive education. If teachers are not knowledgeable about the importance and characteristics of inclusive education, the goal of inclusive education is hard to attain. Therefore, every teachers are expected to have knowledge of inclusive education and skills to implement inclusive education in the classroom context as well as teaching strategies. In addition, they are desirable to have a positive attitude towards keeping all kinds of children in the same classroom and providing them with supports they need individually.

In the above context, this article assesses attitude of teachers towards inclusive education by their age, gender, qualifications, training, disability and teaching experience. Teachers' positive attitude towards inclusive education is an important requirement for effective teaching as Nepal's classrooms are increasingly diverse in terms of students' demographic and disability characteristics. Looking statistically from the database of the Flash II Report published by the Department of Education, there are around 1\% of students in schools in Nepal having some sorts of disability (Department of Education, 2016). Among them, the proportion of students having physical disability is the highest $(0.35 \%)$, followed by intellectual disability $(0.25 \%)$, hearing impairment $(0.15 \%)$, vocal and speech related disabilities $(0.13 \%)$, low vision $(0.11 \%)$, visually impaired (0.02) and hearing and visually impaired (0.02). Teachers' positive attitude towards inclusive education is essential for addressing the learning needs of such diverse students. In this context, the rationale of this study is to assess teachers' attitude towards inclusion and inclusive education and to draw implications for future reform at the level of policy, research and practices.

\section{Methodology}

The study is based on the quantitative survey design which focuses on collecting opinions and experiences from teachers from two integrated and two special schools from Kahtmandu and Lalitpur. From the selected sample schools, the researcher listed down the name of male and female teachers. Then, from male and female strata, the researcher selected 10 male and 10 female teachers from each school (if the number was insufficient, the remaining number was taken from another strata). Altogether, the researcher selected 80 teachers from four sample schools. The criteria for selecting schools and teachers included 1) integrated and inclusive schools, 2) gender, 3 ) having experience of inclusion in the classroom. Despite the researcher's target to include 80 teachers in this study, the number of teachers responded to the questionnaire reduced to 63 . It is because 17 teachers did not respond the questionnaire. This means the response rate of the questionnaire is $79 \%$. 
A Likert Scale was developed and used for studying attitude of teachers regarding the application of inclusive education in an integrated and inclusive classroom environment. For this purpose, 15 statements regarding inclusive education were developed (Annex A). Among them, ten were positive and five were negative statements. Each of these statements was rated in 5-point opinion scale - Strongly Agree (SA), Agree (A), Neutral (N), Disagree (D) and Strongly Disagree (SD). According to the Liker guideline, for positive statements, $\mathrm{SA}$ is given a value of $5, \mathrm{~A}$ of $4, \mathrm{~N}$ of 3, D of 2 and SD of 1 . Similarly, for negative statements, the value is reversed; that is, SA is given a value of $1, \mathrm{~A}$ of $2, \mathrm{~N}$ of $3, \mathrm{D}$ of 4 and $\mathrm{SD}$ of 5 . Therefore, while calculating the value for each statement, the number of respondents is multiplied by appropriate scale-vale and average is calculated. The weightage mean found through the attitude scale ranged from 1 to 5 (Figure 1). As shown in Figure 1 value 2.5 to 5 indicates positive attitude and 1 to 2.5 indicates negative attitude. Value close to 2.5 suggests a neutral opinion (Singh, 2009).

Figure 3. Weightage mean in Likert scale

5

$\begin{array}{llll}\text { Positive attitude } & 2.5 & \text { Negative attitude } & 1\end{array}$

The researcher first drafted the tools and consult with supervisors seeking feedback to make corrections and improvements. Then, she piloted the test in Laboratory Secondary Schools, Kirtipur. After piloting the instruments, she revised or edited the items based on the lessons learnt from administering the instruments. Then, she finalized and printed the items in a required numbers. In order to collect the data, the researcher first prepared, validated and finalized the data collection instruments. Then she requested the Department of Special Needs Education for letter to the schools and teachers to participate in the study and provide required information by filling out the questionnaires. With these letters, the researcher visited the sample schools, meet the head teachers and provide brief introduction of the study. With the permission of head teachers, the researcher administered the survey with individual teachers. The researcher filled out the school survey form with the support of head teachers and non-teaching staff. The collected questionnaires and survey forms were cleaned, edited and prepared for analysis and interpretation.

\section{Inclusive education: A literature review}

The inclusive education movement has been endorsed internationally by UNESCO's Salamanca Statement (UNESCO, 1994) and reflects the United Nation's global strategy of Education for All (Farrell, 2004) Recently, inclusion in education is recognized as a basic human right and the foundation for a more equal society (European Agency for Development in Special Needs Education, 2012). Inclusion in education coined as inclusive education and viewed as an approach, to secure the right to education of children by promoting the educational system. The main purpose of inclusive education is to reduce exclusion in education through ensuring participation of excluded children.

Because of different social and contextual view there is no universally accepted definition of inclusive education. Inclusive education has been conceptualized in many different ways, 
the idea of inclusion within the educational framework is frequently attached to the concepts of mainstreaming, diversity management, learning environments, school cultures, inclusive schools, and equal educational opportunities (Westwood, 2013). Inclusive education mostly concentrated on special need education because disability discourse has very significant role in the development of inclusive education. Nowadays, inclusive education does not only refer to the children with disability, but it also includes all children with or without disability who have some barrier to learning and participation.

Lipskey and Gartner (1997) said that, inclusive education is not a special education but the convergence of the need to restructure the public education system to meet the need of a changing society. Similarly, Forlin (2005) viewed inclusive education much broader than simply inviting children with disabilities into mainstream classrooms and mentioned that, it is a means of extending educational opportunities to marginalized students who are still unable to attend school. Broadly, inclusive education is an innovation of educational development resulted from continuous international debates to reform in education system.

According to Farrell (2004), inclusion in education can be understood in three ways as a) the social inclusion and education of children presently excluded from education $b$ ) the inclusion of pupils currently in mainstream schools, and c) the balance of pupils in mainstream and special schools. It means inclusive education is about both access and participation. It represents the concern of whole school reform. It is focused to effective delivery of quality education to all students and demands equal opportunities for all students whatever their age, gender, ethnicity, attainment or background (Farrell, 2004).

UNESCO (2009) defined inclusive education as a process of strengthening the capacity of the education system to reach out to all learners. UNESCO has developed a framework of inclusive education on the basis of fundamental principles of inclusion which is very relevant to develop inclusive education system.

\section{Inclusive education policies and programs in Nepal}

The Government of Nepal has adopted inclusive education as a main policy for providing children with disability opportunities for learning and overall development. Building on the effort made since 2022 B.S. the government has now implemented inclusive education in education sector in general and school education in particular using various policy tools. Primarily, the government ratified many international and regional conventions regarding education including the Salamanca Declaration (1994). As these international instruments appealed to all party members to make domestic legal and policy provisions for improving universal access in education, Nepal has focused to developed policy with specific reference to inclusive education. The Government has adopted different legal and policy instruments to address the current issues and problems regarding access, participation and opportunities to education.

The Constitution of Nepal strongly protects the human rights on the grounds of religion, race, caste, sex, place of birth and disability. The constitution also ensured the right of education for all without any discrimination. The Article 31 of the Constitution of Nepal mentioned that: a) every 
citizen shall have the right of access to basic education $b$ ) each citizen shall have the right to compulsory and free basic education and free education up to the secondary level c) the physically impaired and citizens who are economically very poor shall have the right to free higher education as provided for in law d) the visually impaired shall have the right to free education with the medium of brail script and citizens with hearing impairment and speech impairment shall have the right to free education with the use of sign language e) every community living in Nepal shall have the right to acquire education in its mother tongue up to the secondary level, and the right to open and run schools and educational institutions as provided by law. Similarly, Article 39 ensured the right of children with stating that every child shall have the right to education, health care, nurturing, appropriate upbringing, sports, recreation and personality development from family and the state (Government of Nepal, 2072 B.S.).

Another the policy of Ministry of Education - Consolidate Equity Strategy, 2014 - has committed to strengthen equity across all levels and subsectors within the school education sector in Nepal. It has realized that inclusive education enable to achieve quality of life and contribute to establishing an equitable and inclusive society that values diversity. The prime objectives of the strategy were set as: a) achieving equity in access, identifying the most marginalized groups of learner that have so far remained unable to access education and thereby able to overcome their barriers in accessing education b) strengthening of equity in participation, retention and inclusion, identifying learners that are currently dropping out of education and addressing their specific barriers both school and non-school based, and c) strengthening the equity in learning outcomes, reducing inequitable learning outcomes and addressing root causes of these discrepancies through targeted interventions focused on removal barriers for learners and catering specific needs (Ministry of Education, 2014).

Nepal's development plans have also underscored the need of inclusive education in schools in particular and kept certain plans and programs to materialize its ideals in classroom. The Tenth Plan (2002-2007) at the first time introduced the term inclusive/integrated education. The plan has aimed to increase the access of education and envisioned the strategy of inclusive and integrated education system according to the concept of special education. The plan had target of increasing access to education of children with special learning needs. Thereafter, the succeeding plans were committed to the extension of equal access in all level and to develop inclusive and equitable education system. Continuing the provision of the previous plans, the ongoing 14th two-year plan (2073/74 - 2075/76 B.S.) continued the target program to increase the access of poor, marginalized and disable people to education and aimed to expand the open, alternative, residential and special education across the country. This plan has clearly mentioned the inclusive education as core strategy to ensure quality and equitable education. It has made the special provision for marginal and deprived community (National Planning Commission, 2016).

Nepal's current inclusive education policy largely focuses on providing maximum support for children with disability in order to succeed in mainstream schools. The current policy - Inclusive Education Policy for Persons with Disabilities 2073 - has acknowledged the constitutional right of every child - including those with some disability - for quality education (Ministry of Education, 2073B.S.). Prior to promulgating this policy, the government was implementing 
Special Education Policy 2053 which had an exclusive focus on providing care, support and opportunity for education for disable children. Considering the fact that special education is inadequate for disable children to adjust in this complex society, this policy has ensured free education for all disable children. Based on the functional assessment of their needs, tailor-made curriculum, textbooks, learning and assessment materials. The policy has made a provision of Inclusive Education Council in order to ensure the right of education for disable persons as well as to make timely revision of inclusive education policy in the country.

The current inclusive education policy for disable persons aims to provide opportunities for formal, non-formal, open, distance and continuous learning. The existing scattered provision of providing scholarship to the disable children will be mainstreamed using a 'one-door' policy. The curricular and assessment materials will be adapted in an accessible format. The educational institutions will have inclusive culture removing biasness and barriers for disable children. The disable persons will have opportunities for acquiring soft and green skills - a sustainable and eco-friendly way of learning skills for their livelihood. A partnership approach will be adopted whereby the government will work with non-government and private sectors to create opportunity for learning for disable persons. The policy has also a provision for a policy coordination committee at the center and appropriate structure for inclusive education at both provincial and local levels. Creating inclusive education minimum enabling conditions, the current policy overall aims to make inclusive education a real transformative reform approach in education sectors in general and school sectors in particular.

The ongoing School Sector Development Program (2016 - 2023) has also included inclusive education as a main policy to strengthen "the institutional capacity to provide inclusive education for children with disabilities and special needs and establishing partnerships with non-state actors and other relevant line ministries to respond to the needs of children with complex or severe disabilities" (Ministry of Education, 2015, p. 32). SSDP aims to update and regularly collect data on the types and prevalence of disability and their levels of severity, updating teacher training to include special education and addressing the social stigma associated with disability. With the aim of equipping teachers with adequate knowledge and skills, SSDP aims to introduce a compulsory inclusive education module in pre-service programs to provide basic knowledge and skills on (i) the needs and abilities of children with special needs, (ii) child-centered pedagogical methods and (iii) active and participative learning techniques, instructional accommodation and activity differentiation. As part of the institutional capacity development, SSDP also has endorsed a policy to scale up the development of skills on inclusive education and children with special needs at the national levels for DOE, NCED and CDC and at district levels for DEOs and assessment center coordinators, supported by relevant academic institutions.

\section{Results and discussions Overall Attitude}

Overall teachers are found positive towards inclusive education. The average attitude value for various statements of inclusive education is 3.32 which shows that teachers are generally positive towards inclusive education. Among 15 statements regarding inclusive education, teachers shows 
Teachers' Attitude Towards Inclusive Education in Nepal/ 179

positive attitude in 12 statements (value 2.5 to 5 , see Appendix A). They show extremely positive attitude towards some aspects of inclusive education, such as:

Statement 5 - Inclusive education programs provide students with opportunities for mutual communication, thus promote students to understand and accept individual diversity (Value 4.33)

Statement 3 - Inclusive education is likely to have a positive effect on the social and emotional development of students with disabilities (Value 4.41)

Teachers are negative only in the following three statements:

Statement 7 - There are sufficient supportive resources and professional teachers to support inclusive education in regular school (2.40).

Statement 11 - Statement Inclusive education have more challenges to implement in classroom in the context of Nepal (1.94).

Statement 13 - Children with multiple disabilities should be educated in special, separate settings (1.70).

The statements of inclusive education and related results (Appendix A) suggests that teachers are generally positive in all aspects of inclusive education, indicating that they are enthusiastic to implement inclusive education in schools provided that they are equipped with necessary resources, policies and facilities. Teachers disagree with the fact that 'there are sufficient supportive resources and professional teachers to support inclusive education in regular school', While teachers face problems of resources in schools, it is hard to materialize the purposes of inclusive education. In such a situation, inclusive education becomes more an ideal than a reality. Teachers strongly held a view that "Inclusive education is likely to have a positive effect on the social and emotional development of students with disabilities" suggesting the fact that in additional to resources, facilities and policies, they are to be equipped with necessary knowledge and skills required for implementing inclusive education in classroom. As teachers also strongly believe that it is difficult to train teachers to use different teaching methods to teach students with disabilities more effectively, they are to be trained to use multiple teaching strategies to help students of different learning needs. Overall, as teachers are positive towards inclusive education, the policy makers should make a realistic plan to provide teachers with both professional development opportunities (e.g. training) as well as resources required to implement ideals of inclusive education in the classroom.

\section{Attitude by gender}

In this study, Participation of male and female teachers was nearly equal. Of 63 teachers, 30 (47.6\%) were male and remaining 33 (52.4\%) were female. The teachers represented all caste and ethnic groups. Regarding attitude by gender, male teachers' attitude towards inclusive education is found slightly greater than that of female teachers. Male teachers' average attitude 
is 3.37 whereas female teachers' attitude is 3.27 . Attitude of male and female teachers towards inclusive education is shown in Table 1.

Table 1. Attitude by gender

\begin{tabular}{|l|c|c|}
\hline & Male & Female \\
\hline Number & $30(47.6 \%)$ & $33(52.4 \%)$ \\
\hline Attitude (Likert average) & 3.37 & 3.27 \\
\hline
\end{tabular}

Source: Field Survey, 2018

The gender composition of the participants suggests that there are nearly equal proportion of male and female in the study. Therefore, the result of the study is truly represented by both gender. The gender representation also helps to ensure that the opinion expressed by teachers are gender-representative and valid to understand attitude of both male and female teachers. Gender difference in attitude towards inclusive education is an issue for further investigation, especially regarding the extent to which this difference is statistically significant and if yes, what are the factors are associated with it.

\section{Attitude by age}

The age of teachers is organized in four category: 20-30 years, 30-40 years, 40-50 years, and above 50 years. The results show that a majority of teachers are young who are in between 20 to 40 years of age. Results for age groups are as follow: 19 (30.19\%) teachers were aged 20 to 30 years old, 18 (28.57\%) were aged 30 to 40,17 (26.98\%) teachers were aged 40 to 50 years old, $5(7.93 \%)$ were aged 50 years old and above. It is noted that 4 (four) teachers did not provide information about their age.

Table 2. Age category of teachers

\begin{tabular}{|l|c|c|}
\hline Age category & $\mathrm{N}$ & $\%$ \\
\hline $20-30$ yrs & 19 & 30.15 \\
\hline $30-40$ yrs & 18 & 28.57 \\
\hline $40-50$ & 17 & 26.98 \\
\hline Above 50 & 5 & 7.93 \\
\hline Total & 59 & 93.63 \\
\hline
\end{tabular}

Source: Field Survey, 2018

Regarding attitude of teacher by gender, younger (age below 40) teachers' attitude is found more positive towards inclusive education than that of older (above 40) ones. Younger teachers' average attitude towards inclusive education is 3.46 whereas the same of older teachers is 3.14 . Attitude of younger and older teachers towards inclusive education is shown in Table 3.

Table 3. Attitude by age

\begin{tabular}{|l|c|c|}
\hline & Young (40 and below 40) & Old (Above 40) \\
\hline No. & 35 & 28 \\
\hline Attitude (Likert average) & 3.46 & 3.14 \\
\hline
\end{tabular}

Source: Field Survey, 2018 
As the above table suggests, the participants in this study represent largely the young group of teachers. Therefore, the result of this study could largely be represented by the teachers with age below 50 years. The relatively younger teachers' perception is expected to provide policy makers a genuine concern about inclusive education and helps them to revise policy according to their experience and suggestions. The above result suggests that while implementing inclusive education in schools it is good to have younger teachers in schools. Training opportunity should be given more to the older teachers than younger ones.

\section{Attitude by qualification}

One of the aims of this study is to assess the attitude of teachers towards inclusive education based on their qualifications. Accordingly, this study has explored teachers' highest academic qualification and explore the attitude of the teachers having Master degree qualification and lower. The result of highest qualification of teachers is summarized in Table 4.

Table 4. Highest qualification of teachers

\begin{tabular}{|l|c|c|}
\hline Qualification & $\mathrm{N}$ & $\%$ \\
\hline SLC & 1 & 1.59 \\
\hline+2 or Intermediate & 8 & 12.70 \\
\hline Bachelors & 14 & 22.22 \\
\hline Master's degree & 40 & 63.49 \\
\hline Total & 63 & 100 \\
\hline
\end{tabular}

Source: Field Survey, 2018

Table 4 shows that 14 (22.22\%) of teachers received Bachelor's degree while $40(63.49 \%)$ teachers had Master's degree. Only $1(1.59 \%)$ teachers had SLC and $8(12.70 \%)$ had intermediate degree (e.g. 10+2) qualification. It is more likely that the more educated teachers tended to be more supportive to the children with or without disability than lesser educated ones. Therefore, the highest number of teachers having Master's Degree qualification shows a positive sign that teachers may have sufficient knowledge to help children of all kinds. The views and information of this study, largely represented by the teachers having Master Degree qualifications. Views of teachers having Bachelor's and Master Degree qualifications mean that teachers' understanding and opinion are based on both their theoretical understanding and practical experience.

As regards attitude by qualification, teachers with higher qualifications (e.g. Master degree) are found more positive towards inclusive education than teachers with lower qualifications (SLC to Bachelor). Teachers with Master's degree qualifications, for example, have an average attitude 3.40 in Likert scale and teachers with SLC to Bachelor degree qualification have an average of 3.18. Attitude of highly qualified (Master's degree) and other (Bachelor degree or low) teachers towards of inclusive education is shown in Table 5.

Table 5. Attitude by qualification

\begin{tabular}{|l|c|c|}
\hline & SLC to Bachelor & Master \\
\hline No. & 23 & 40 \\
\hline Attitude (Likert average) & 3.18 & 3.40 \\
\hline
\end{tabular}

Source: Field Survey, 2018 
Table 5 suggests that the government should prefer to hire teachers with higher qualification to implement inclusive education in schools. In addition, teachers with lower qualifications should be given opportunity (such as study leave) to upgrade their qualifications.

\section{Attitude by training}

Only $27 \%$ teachers are found to have received some forms of training in inclusive education. Out of 63 teachers surveyed only 17 received training in inclusive education and other 45 teachers did not (one teacher did not reveal his/her training status). Those who received training in inclusive education ranges from one day orientation to a week-long training.

Regarding attitude by training, trained teachers' attitude towards inclusive education is found more positive than untrained teachers. As Table 4.9 depicts, trained teachers' average attitude in Likert scale is 3.59 whereas untrained teachers' average 3.22. Attitude of trained and untrained teachers towards inclusive education is shown in Table 6.

Table 6. Attitude by training

\begin{tabular}{|l|c|c|l|}
\hline & Trained & Untrained & Remarks \\
\hline No. & $17(26.98 \%)$ & $45(71.43 \%)$ & $\begin{array}{l}\text { One teacher did not respond } \\
\text { his/her training status }\end{array}$ \\
\hline Attitude (Likert average) & 3.59 & 3.22 & \\
\hline
\end{tabular}

Source: Field Survey, 2018

The positive attitude of trained teachers suggests that training teachers received about inclusive education is effective to develop positive attitude towards inclusion of diverse children in the classroom and teach them using the ideals of inclusive education.

\section{Attitude by experience}

The study found that a majority of the teachers have reasonable experience (more than 5 years) of teaching in different schools. According to the findings, $6(9.52 \%)$ teachers had taught for 0-5 years, $16(25.40 \%)$ had taught for 5 to 10 years, $28(44.45 \%)$ had taught 10 to 20 years and $13(20.63 \%)$ had taught 20 to 30 years. Therefore, the study reveals that the majority of teachers of sample schools are experienced in teaching. Table 7 shows that teaching experience of the respondent teachers.

Table 7. Teaching experiences of teachers

\begin{tabular}{|l|c|c|}
\hline Experiences & $\mathrm{N}$ & $\%$ \\
\hline Below 5 yrs & 6 & 9.52 \\
\hline $5-10$ & 16 & 25.40 \\
\hline $10-20$ & 28 & 44.45 \\
\hline $20-30$ & 13 & 20.63 \\
\hline Total & 63 & 100 \\
\hline
\end{tabular}

Source: Field Survey, 2018 
Table 7 suggests that a great majority of teachers took part in this study are experienced ones, meaning the opinion and experiences represented in this study represent the teachers of having reasonable experience of teaching. Most of the teachers have some experience in inclusive classroom setting. However, they have different levels of experience in terms of teaching strategies, classroom management, assessment and student support in order to help students of different needs and capacities.

Regarding attitude by experience, teachers with more than 10 years of teaching experience are found more positive than the teachers with the less experience of teaching. Teachers with more than 10 years of experience have average 3.42 in Likert Scale while the less experienced teachers have an average of 3.29. Attitude of teachers with higher experience (10 or more years) and lower experience (below $10 \mathrm{yrs}$ ) towards inclusive education is shown in Table 8.

Table 8. Attitude by experience

\begin{tabular}{|l|c|c|}
\hline & 10 and below 10 years & Above 10 years \\
\hline No. & 22 & 41 \\
\hline Attitude (Likert average) & 3.29 & 3.42 \\
\hline
\end{tabular}

Source: Field Survey, 2018

Table 8 suggests that experience in teaching is important in effectively implementing inclusive education. The implication of this result is that experienced teachers are to given opportunity in planning, designing, implementing and evaluating curricular and extracurricular programs regarding inclusive education.

\section{Attitude by disability status}

In this research, a small number of teachers $(\mathrm{N}=7)$ were disable of some kinds. This constitutes $11 \%$ of the total respondents. Remaining $89 \%$ teachers did not reported to have any kind of disability. Among seven teachers having some disability, two teachers have physical disability and others five have visual impairment with varying degree.

Table 9. Disability characteristics of teachers

\begin{tabular}{|l|c|c|}
\hline Characteristics & $\mathrm{N}$ & $\%$ \\
\hline Teacher with disability & 7 & 11.11 \\
\hline Teacher without disability & 56 & 88.89 \\
\hline Total & 63 & 100 \\
\hline
\end{tabular}

Source: Field Survey, 2018

The sample represents a significant number of teachers who have some types of disability. So while collecting attitude of teachers towards inclusive education, this study captures views of both groups - having and not having disability. This composition of teachers suggests that the perception collected in this study represents of teachers with and without disability.

Concerning attitude, teachers having some disability are found more positive towards inclusive education than non-disable teachers. As shown in Table 10, teachers with some disability have 
average attitude 3.59 in Likert scale whereas average attitude of other teachers in the same scale is 3.30. Attitude of disable and non-disable teachers towards inclusive education is shown in Annex $\mathrm{O}$ and $\mathrm{P}$.

Table 10. Attitude by disability characteristics

\begin{tabular}{|l|c|c|}
\hline & Disable teachers & Non-disable teachers \\
\hline No. & 7 & 56 \\
\hline Attitude (Likert average) & 3.51 & 3.30 \\
\hline
\end{tabular}

Source: Field Survey, 2018

The above results suggests that some of the non-disable teachers are still not fully positive towards the inclusion of disable and other minority children in the classroom and use the approach of inclusive education in the classroom. This result further suggests that programme and training for non-disable teachers focusing on inclusive education required in a greater scale.

\section{Conclusion}

Teachers in integrated and special schools are generally positive towards inclusive education. However, as Nepal's inclusive education practice is nascent; it takes time for teachers from all schools to develop positive attitude towards inclusive education. While teachers in integrated and inclusive schools were found qualified and aware of the notion of inclusive education grounded on the human right perspectives (Regmi, 2017), this may not be the case of all general schools across the country. The policies and programs of inclusive education and other educational reform in general are largely donor drive (Maudslay, 2014), the bottom-up approach of policy making is must, assessing needs of students, teachers and schools at the deeper level. This helps to create a realistic policy and program of inclusive education that specifies the kinds of support school and teachers need in order to implement the notion of inclusive education in classroom and school. As pointed out in the Human Rights Watch (2011) study, the attitude of people is not a problem for inclusion, because people in Nepal are generally accommodative, welcoming, friendly and respectful for each other. Rather, a heavy dependency on donor-driven agendas and polices and poor implementation of such policies in local and rural context is a key issue in Nepal.

Considering the provision of Nepalese policies (Ministry of Education, 2073BS; National Planning Commission, 2016), it is worthwhile to note that while policy provisions include every requirements for implementing inclusive education in the classroom, the professional development support and resources available are not adequate. There are also the problems of teachers' heavy workload so that they are not able to provide extra care and support to the children with special ability and needs. It seems that the government has committed to implementing the provisions and programs agreed upon in Salamanca Declaration (UNESCO, 1994) which is reflected in the constitution ensuring rights of education of all children regardless of their physical and other forms of disability. As argued by different scholars discussed in the literature review section (e.g. Lipskey and Gartner, 1997; Farrell, 2004; Forlin 2005; Berlach \& Chambers, 2011; UNESCO, 2011, Mittler, 2012), Nepal's policies of inclusive education underscore the need of supportive culture in the schools where every disable students feel welcoming at schools 
and thereby prosper and utilize their ability and talent and prepare themselves to live happily and successfully in their societies.

As other studies (Shrestha, 2017; Maharjan Shrestha, 2017) also suggest, teachers have positive attitude and somehow skilled in implementing various teaching strategies and approaches of inclusive education in the classroom. While looking at the teachers' knowledge about inclusive education, it is learnt that most of them have fair degree of knowledge and understanding that inclusive education is not only about accommodating disable children in mainstream classes, but also an approach to change the school culture with a motivating mindset of teachers and parents that every child is unique and they can learn if a conducive environment is created and if they are treated with care and respect. Teachers' use of teaching strategies, classroom management, use of adaptive materials suggest that they are somehow familiar with various dimensions of inclusion education (Berlach \& Chambers, 2011; UNESCO, 2011, Mittler, 2012). While some teachers are not much familiar with the strategies of disability management and adaptive pedagogy, most of the teachers are found concerned with classroom management and providing disable children with opportunities for communication, socialization, happiness and learning.

There are further requirements for helping teachers to have positive attitude towards inclusive education. At the practice level, for example, teachers need to have opportunity for their continuous professional development so that they are acquainted with up-to-date knowledge, skills and strategies of inclusive education. In addition, they are to be provided necessary resources and facilities for implementing the various approaches, strategies and dimensions of inclusive education. Teachers' expressed that they have difficulties in time management as most of them have a full workload in the schools. The rigidity of existing curriculum, as many teachers shared, contradicts the notion of inclusive education. While teachers are in favor of flexible curriculum in order adapt and tailor them to the needs of the students, this supports the notion of inclusive education suggested by many scholars (e.g. Grenier, 2010; Messiou 2012). It is equally important to help teachers to use adaptive methods of assessment (Forlin 2005; Stofile 2008) for students with diverse learning needs as many teachers suggest that assessment of learning of disable children is always a daunting task. In addition, teachers need support to manage and plan extracurricular activities for disable children as well as for using various adaptive teaching techniques for the students with diverse learning needs. Providing continuous professional development opportunities could enhance teachers' knowledge and skills in using adaptive teaching, assessment and extracurricular activities for students' with special ability and needs. In this context, this article attempts to put the idea of

\section{References}

Berlach, R. G. \& Chambers, D. J. (2011). Inclusivity imperatives and Australian national curriculum. The Education Forum, 75, 52-65.

Central Bureau of Statistics (2014). The Population Monograph of Nepal. Kathmandu: Author

Department of Education (2016). Flash II Report 2072. Kathmandu: Author.

European Agency for Development in Special Needs Education (2012). The Inclusive Education in Action Project. Retrieved from https://www.europen-agency.org/agency project/iea. 
Farrell, M. (2004). Understanding Special Educational Needs: A Guide for Student Teacher. London: Routledge Falmer.

Farrell, M. (2004). Understanding Special Educational Needs: A Guide for Student Teacher. London: Routledge Falmer.

Forlin, L. (2005). Inclusion, special needs and search for new understandings. Support for Learning, 20 (2), 96-98.

Government of Nepal (2072BS). The Constitution of Nepal. Kathmandu: Government of Nepal.

Grenier, M. (2010). Moving to inclusion: A socio-cultural analysis of practice. International Journal of Inclusive Education, 14 (4), 387-400.

Human Rights Watch (2011). Futures stolen: barriers to education for children with disabilities in Nepal. New York, NY: Human Rights Watch.

Lipskey, D. K. \& Gartner, A. (1997). Inclusion and School Reform: Transforming America's Classrooms. Baltimore, MD: Brooks.

Maharjan Shrestha, R. (2017). Inclusive Education in Nepal: Teachers' understanding and classroom practices. Unpublished M.Phil. Thesis. Graduate School of Education, Tribhuvan University.

Maudslay, L. (2014). Inclusive education in Nepal: Assumptions and reality, Childhood, 21(3), 418-424.

Messiou, K. (2012). Confronting Marginalization in Education: A Framework for Promoting Inclusion. London: Routledge.

Ministry of Education (2014). Consolidate Equity Strategy, 2014. Kathmandu: Author.

Ministry of Education (2015). School Sector Reform Programme (2016- 2023). Kathmandu: Author.

Ministry of Education (2073B.S.). Inclusive Education Policy for Persons with Disabilities 2073. Kathmandu: Author.

Mittler, P. (2012). Overcoming Exclusion: Social Justice through Education. Abington, UK: Routledge.

National Planning Commission (2016). The Fourteenth Plan (Fiscal Year 2073/74 - 2075/76). Kathmandu: National Planning Commission.

Regmi, N.P. (2017). Inclusive education in Nepal: From theory to practice. An unpublished MPhil thesis. Ludwig Maximilian University.

Shrestha, S. (2017). Teachers' attitude towards inclusion of students with intellectual disability in community schools in Nepal. An unpublished MPhil thesis. Kathmandu University.

Singh, A.K. (2009). Tests, Measurements and Research Methods in Behavioural Sciences. New Delhi: Bharati Bhawan. 
Stofile, S. Y. (2008). Factors Affecting the Implementation of Inclusive Education Policy: A Case Study in One Province in South Africa (PhD Thesis). Cape Town: University of the Western Cape.

UNESCO (1994). World Conference on Special Needs Education: Access and Quality, includes Salamanca Declaration and Framework for Action. Paris: UNESCO.

UNESCO (2009). Policy Guidelines on Inclusion in Education. Paris: UNESCO.

UNESCO (2011). Education: Inclusive Education. Retrieved in 18 January 2016 from https:// www.unesco.org/new/en/educationa/themes/strengthening-education system/inclusiveeducation/.

United Nations (1948). Universal Declaration of Human Rights. Washington, DC: United Nations. 


\section{Appendix A}

\section{Teachers' attitude towards various statements about inclusive education}

\begin{tabular}{|c|c|c|c|c|c|c|c|c|}
\hline \multirow{2}{*}{$\begin{array}{l}\text { S. } \\
\text { N. }\end{array}$} & \multirow{2}{*}{ Statement } & \multicolumn{5}{|c|}{ Number of teachers' responses } & \multirow{2}{*}{$\begin{array}{c}\text { Weightage } \\
\text { mean }\end{array}$} & \multirow{2}{*}{ Attitude } \\
\hline & & SA & $\mathrm{A}$ & $\mathrm{N}$ & $\mathrm{D}$ & SD & & \\
\hline 1 & $\begin{array}{l}\text { All children regardless of their } \\
\text { specificity and uniqueness should } \\
\text { be educated in regular class. }\end{array}$ & \begin{tabular}{|c|}
21 \\
$33.33 \%$
\end{tabular} & $\begin{array}{c}24 \\
38.09 \%\end{array}$ & \begin{tabular}{|c|}
7 \\
$11.11 \%$
\end{tabular} & $\begin{array}{c}6 \\
9.5 \%\end{array}$ & $\begin{array}{c}5 \\
7.9 \%\end{array}$ & 3.79 & + ve \\
\hline 2 & $\begin{array}{l}\text { Both students with and without } \\
\text { disabilities can get academic } \\
\text { improvement because of inclusive } \\
\text { education. }\end{array}$ & $\begin{array}{c}21 \\
33.33 \%\end{array}$ & $\begin{array}{c}28 \\
44.44 \%\end{array}$ & $\begin{array}{c}4 \\
6.34 \%\end{array}$ & $\begin{array}{c}8 \\
12.63 \%\end{array}$ & $\begin{array}{c}2 \\
3.17 \%\end{array}$ & 3.92 & + ve \\
\hline 3 & $\begin{array}{l}\text { Inclusive education is likely } \\
\text { to have a positive effect on the } \\
\text { social and emotional development } \\
\text { of students with disabilities. }\end{array}$ & $\begin{array}{c}34 \\
53.96 \%\end{array}$ & $\begin{array}{c}26 \\
41.26 \%\end{array}$ & 0 & $\begin{array}{c}1 \\
1.58 \%\end{array}$ & $\begin{array}{c}2 \\
3.17 \%\end{array}$ & 4.41 & + ve \\
\hline 4 & $\begin{array}{l}\text { The needs of students with } \\
\text { disabilities can be best served in } \\
\text { special, separate settings. }\end{array}$ & $\begin{array}{c}15 \\
23.80 \%\end{array}$ & $\begin{array}{c}31 \\
49.20 \%\end{array}$ & $\begin{array}{c}10 \\
15.87 \%\end{array}$ & $\begin{array}{c}6 \\
9.52 \%\end{array}$ & $\begin{array}{c}1 \\
1.58 \%\end{array}$ & 3.84 & + ve \\
\hline 5 & $\begin{array}{l}\text { Inclusive education programs } \\
\text { provide different students } \\
\text { with opportunities for mutual } \\
\text { communication, thus promote } \\
\text { students to understand and accept } \\
\text { individual diversity. }\end{array}$ & $\begin{array}{c}27 \\
42.85 \%\end{array}$ & $\begin{array}{c}32 \\
50.79 \%\end{array}$ & $\begin{array}{c}3 \\
4.76 \%\end{array}$ & 0 & $\begin{array}{c}1 \\
1.58 \%\end{array}$ & 4.33 & + ve \\
\hline 6 & $\begin{array}{l}\text { Children who communicate in } \\
\text { special ways (e.g., sign language) } \\
\text { should be educated is special, } \\
\text { separate settings. }\end{array}$ & $\begin{array}{c}13 \\
20.63 \%\end{array}$ & $\begin{array}{c}24 \\
38.09 \%\end{array}$ & $\begin{array}{c}10 \\
15.87 \%\end{array}$ & $\begin{array}{c}14 \\
22.22 \%\end{array}$ & $\begin{array}{c}2 \\
3.17 \%\end{array}$ & 3.51 & + ve \\
\hline 7 & $\begin{array}{l}\text { There are sufficient supportive } \\
\text { resources and professional } \\
\text { teachers to support inclusive } \\
\text { education in regular school. }\end{array}$ & $\begin{array}{c}6 \\
9.52 \%\end{array}$ & $\begin{array}{c}7 \\
11.11 \%\end{array}$ & $\begin{array}{c}10 \\
15.87 \%\end{array}$ & $\begin{array}{c}23 \\
36.50 \%\end{array}$ & $\begin{array}{c}17 \\
26.98 \%\end{array}$ & 2.40 & -ve \\
\hline 8 & $\begin{array}{l}\text { I have corresponding knowledge } \\
\text { and skills to educate students with } \\
\text { disabilities. }\end{array}$ & $\begin{array}{c}11 \\
17.46 \%\end{array}$ & $\begin{array}{c}21 \\
33.33 \%\end{array}$ & $\begin{array}{c}19 \\
30.15 \%\end{array}$ & $\begin{array}{c}8 \\
12.69 \%\end{array}$ & $\begin{array}{c}4 \\
6.34 \%\end{array}$ & 3.43 & $+\mathrm{ve}$ \\
\hline 9 & $\begin{array}{l}\text { Regular education teachers' } \\
\text { instructional effectiveness will be } \\
\text { enhanced by having students with } \\
\text { disabilities in regular class. }\end{array}$ & $\begin{array}{c}13 \\
20.63 \%\end{array}$ & $\begin{array}{c}36 \\
57.14 \%\end{array}$ & $\begin{array}{c}8 \\
12.69 \%\end{array}$ & $\begin{array}{c}4 \\
6.34 \%\end{array}$ & $\begin{array}{c}2 \\
3.17 \%\end{array}$ & 3.86 & $+\mathrm{ve}$ \\
\hline 10 & $\begin{array}{l}\text { I feel comfortable working with } \\
\text { students with disabilities and their } \\
\text { parents. }\end{array}$ & $\begin{array}{c}8 \\
12.69 \%\end{array}$ & $\begin{array}{c}38 \\
60.31 \%\end{array}$ & $\begin{array}{c}10 \\
15.87 \%\end{array}$ & $\begin{array}{c}5 \\
7.93 \%\end{array}$ & $\begin{array}{c}2 \\
3.17 \%\end{array}$ & 3.71 & + ve \\
\hline
\end{tabular}


Teachers' Attitude Towards Inclusive Education in Nepal/ 189

\begin{tabular}{|c|c|c|c|c|c|c|c|c|}
\hline 11 & $\begin{array}{l}\text { Inclusive education have more } \\
\text { challenges to implement in } \\
\text { classroom in the context of } \\
\text { Nepal. }\end{array}$ & $\begin{array}{c}20 \\
31.74 \%\end{array}$ & $\begin{array}{c}34 \\
53.96 \%\end{array}$ & $\begin{array}{c}3 \\
4.76 \%\end{array}$ & $\begin{array}{c}5 \\
7.93 \%\end{array}$ & $\begin{array}{c}1 \\
1.58 \%\end{array}$ & 1.94 & - ve \\
\hline 12 & $\begin{array}{l}\text { Inclusive education is ideal than } \\
\text { a solution while considering } \\
\text { diversity of children in Nepal. }\end{array}$ & $\begin{array}{c}11 \\
17.46 \%\end{array}$ & $\begin{array}{c}21 \\
33.33 \%\end{array}$ & $\begin{array}{c}10 \\
15.87 \%\end{array}$ & $\begin{array}{c}12 \\
19.04 \%\end{array}$ & $\begin{array}{c}9 \\
14.28 \%\end{array}$ & 2.79 & $+\mathrm{ve}$ \\
\hline 13 & $\begin{array}{l}\text { Children with multiple disabilities } \\
\text { should be educated in special, } \\
\text { separate settings. }\end{array}$ & $\begin{array}{c}37 \\
58.73 \%\end{array}$ & $\begin{array}{c}17 \\
26.98 \%\end{array}$ & $\begin{array}{c}3 \\
4.76 \%\end{array}$ & $\begin{array}{c}3 \\
4.76 \%\end{array}$ & $\begin{array}{c}3 \\
4.76 \%\end{array}$ & 1.70 & - ve \\
\hline 14 & $\begin{array}{l}\text { It is difficult to train teachers to } \\
\text { use different teaching methods } \\
\text { to teach students with disabilities } \\
\text { more effectively. }\end{array}$ & $\begin{array}{c}8 \\
12.69 \%\end{array}$ & $\begin{array}{c}14 \\
22.22 \%\end{array}$ & $\begin{array}{c}6 \\
9.52 \%\end{array}$ & $\begin{array}{c}25 \\
39.68 \%\end{array}$ & $\begin{array}{c}10 \\
15.87 \%\end{array}$ & 3.24 & + ve \\
\hline 15 & $\begin{array}{l}\text { Inclusion sounds good in theory } \\
\text { but does not work well in } \\
\text { practice. }\end{array}$ & $\begin{array}{c}7 \\
11.11 \%\end{array}$ & $\begin{array}{c}18 \\
28.57 \%\end{array}$ & $\begin{array}{c}16 \\
25.39 \%\end{array}$ & $\begin{array}{c}12 \\
19.04 \%\end{array}$ & $\begin{array}{c}10 \\
15.87 \%\end{array}$ & 3.00 & + ve \\
\hline \multicolumn{7}{|c|}{ Average } & 3.32 & $+v e$ \\
\hline
\end{tabular}

